\title{
A Review of Water Stress and Water Footprint Accounting
}

\author{
Dan Wang ${ }^{1}$, Klaus Hubacek ${ }^{1, *} \mathbb{C}$, Yuli Shan ${ }^{1, *}$, Winnie Gerbens-Leenes ${ }^{1}\left(\mathbb{D}\right.$ and Junguo Liu ${ }^{2}$ \\ 1 Integrated Research on Energy Environment and Society (IREES), Energy Sustainability Research Institute \\ Groningen (ESRIG), University of Groningen, 9747 AG Groningen, The Netherlands; \\ dan.wang@rug.nl (D.W.); p.w.leenes@rug.nl (W.G.-L.) \\ 2 School of Environmental Science and Engineering, Southern University of Science and Technology, \\ Shenzhen 518055, China; liujg@sustc.edu.cn \\ * Correspondence: k.hubacek@rug.nl (K.H.); y.shan@rug.nl (Y.S.)
}

check for

updates

Citation: Wang, D.; Hubacek, K.;

Shan, Y.; Gerbens-Leenes, W.; Liu, J. A Review of Water Stress and Water Footprint Accounting. Water 2021, 13, 201. https://doi.org/10.3390/ w13020201

Received: 28 October 2020 Accepted: 12 January 2021 Published: 15 January 2021

Publisher's Note: MDPI stays neutral with regard to jurisdictional clai$\mathrm{ms}$ in published maps and institutional affiliations.

Copyright: $\odot 2021$ by the authors. Licensee MDPI, Basel, Switzerland. This article is an open access article distributed under the terms and conditions of the Creative Commons Attribution (CC BY) license (https:// creativecommons.org/licenses/by/ $4.0 /)$.

\begin{abstract}
Production and consumption activities deplete freshwater, generate water pollution and may further lead to water stress. The accurate measurement of water stress is a precondition for sustainable water management. This paper reviews the literature on physical water stress induced by blue and green water use and by water pollution. Specifically, we clarify several key concepts (i.e., water stress, scarcity, availability, withdrawal, consumption and the water footprint) for water stress evaluation, and review physical water stress indicators in terms of quantity and quality. Furthermore, we identify research gaps in physical water stress assessment, related to environmental flow requirements, return flows, outsourcing of water pollution and standardization of terminology and approaches. These research gaps can serve as venues for further research dealing with the evaluation and reduction of water stress.
\end{abstract}

Keywords: water footprint; water stress; water scarcity; water quality

\section{Introduction}

With the rapidly increasing human population, economic growth, expansion of irrigated agriculture and changing consumption patterns, water shortages and pollution have become serious global issues [1-4] threatening human health, the living environment and sustainable development $[5,6]$. Globally, two billion people live in countries under conditions of high-water stress [7], four billion people experience severe water stress at least one month per year, and 1.8 billion people at least six months per year [8]. Estimates show that by 2050, over half of the global population will live in water-stressed regions [9]. In addition, millions of people die from diseases associated with water shortage and water pollution every year [10-12]. It is apparent that clean freshwater has become an increasingly limited natural resource for humans. Insufficient or unsuitable available freshwater resources already impact human and ecosystem health, energy supply, food security, and human livelihoods, globally $[6,9,13,14]$. Addressing water stress has been an urgent target for the United Nations Sustainable Development Goals (SDGs) [9,13], with a high level of interdependencies with other SDGs [15]. The World Economic Forum reported that water stress is one of the top risks of today [16]. As such, there is an urgent need to solve water stress problems.

These needs and urgency have triggered a large increase in water stress-related research [4]. But most studies focus on stress induced by blue water use [17,18] (refering to water use from surface freshwater and groundwater). Nevertheless, water pollution and green water use also exacerbate water stress [19-21]. Green water refers to "the precipitation on land that does not run off or recharge the groundwater but is stored in the soil or temporarily stays on top of the soil or vegetation" ([22], p. 189). Green water is a major contributor to the production of food, feed, fibers, timber and bioenergy [23-25]. Green water consumption accounted for $74 \%$ of global annual average freshwater consumption in the period 19962005, whereas blue water consumption and grey water footprint (freshwater consumed to 
dilute pollutants to satisfy specific water quality standards) accounted for only $11 \%$ and $15 \%$, respectively [23]. Given its importance to the production of agricultural products and the fact that many regions in Europe, Central America, the Middle East, and South Asia encounter green water stress [18], green water cannot be ignored in water stress assessment. Another important component of water stress is induced by discharged polluted wastewater from industry, households and agriculture contributing to water quality deterioration and posing further constraints on water usability [21,26]. But only few studies considered water stress induced by water pollution $[17,19,21,27-29]$. As a result, water quantity stress induced by blue and green water use and water quality stress induced by pollution provide important and complementary information [17].

During the last four decades, there have been a few review papers on how to measure water stress. For example, Brown and Matlock [30] reviewed primary water stress indicators and methodologies, providing a brief overview for blue water stress and characteristics for each blue water stress indicator, but without considering green water and water pollution. Liu et al. [4] reviewed nine water quantity stress indicators, providing a timeline for the introduction of each water stress indicator and presenting suggestions on incorporating green water, water quality and environmental flow requirements in water stress measurements. Rijsberman [31] reviewed in detail strengths and weaknesses of four blue water stress indicators: per capita water availability, withdrawal-to-availability indicator, physical and economic scarcity indicators and the water poverty index. The paper also discusses water stress at global and regional levels and implications for policy. Vanham et al. [32] discussed whether the Sustainable Development Goals' water quantity stress indicator considers a number of essential elements and made suggestions on how to improve blue water stress assessment providing in-depth insights and principles for using and further developing water stress indicators. Damkjaer and Taylor [33] reviewed commonly employed blue water stress metrics. They highlighted weaknesses of these indicators and critically examined how to best measure water stress. But their review is mainly concerned with the characterization of water stress in developing countries in tropical areas. Schyns et al. [20] provided a very detailed review on three green water scarcity indicators and 80 green water availability indicators. It was the first review article that focused on green water scarcity broadening the scope of water stress assessment [20].

The aim of this review paper is to give an overview of the literature on how to measure physical water stress. Physical water stress means that there is not enough water (in terms of quantity and quality) to meet all demand (including requirements of ecosystems) [34], and it does not include social, economic and political aspects of water stress. To review how to measure physical water stress, we clarify a few key concepts for water stress evaluation, and then review commonly used physical water stress indicators and summarize approaches to account for water footprints (blue, green and grey water footprints). Finally, issues and gaps are identified to improve water stress assessment and provide future directions for water stress studies. We performed the literature search using the keywords "water stress", "water scarcity" and "water footprint" through Google Scholar. Not all articles have been incorporated in the text as that would have been too many, but we mainly refer to key contributions, highly cited or the first publication that introduced a certain topic. The literature review was stopped on a specific aspect when 'theoretical saturation' was achieved [35], or in other words, when references on that topic did not add any new insights.

\section{Key Concepts for Water Stress Measurement}

Physical water stress and scarcity are often used interchangeably, or the exact nature of the underlying data is not clearly defined or justified (e.g., water use versus consumption versus withdrawal) [36-38]. A number of authors have noted that there is no widely accepted definition for physical water stress and scarcity $[31,39,40]$. We summarize different definitions for physical water stress and scarcity in Table 1. It is broadly understood that water has a quantity and quality dimension, both providing two sides of the same coin. 
Water scarcity is either seen through a quantity [32,39,41] or quality point of view [21], and less frequently from both dimensions $[4,17,19,27]$. Likewise, the concept of water stress has been mainly used to refer to the quantity dimension [32,42-46], and to a lesser extent to both quantity and quality dimensions $[47,48]$.

Comparing different definitions of water stress and scarcity in Table 1, we find that they seem to be converging on the definition given by the CEO Water Mandate [47], comparing many different water stress and scarcity definitions based on a lengthy expert consultation on definitions, aimed at reaching an agreement on terminology. CEO Water Mandate defines water scarcity as lack of physical abundance of freshwater resources without considering whether water is suitable for use, and water stress as lack of ability to meet human and ecological demand for freshwater, in terms of water quantity and quality and accessibility to water.

Water availability refers to both available green and blue water [20,49]. However, researchers mainly consider blue water availability, almost by default. But green water availability is also important especially for crop production, grazing lands, forestry and terrestrial ecosystems [20,22]. Thus, blue and green water availability need to be considered in their own right providing complementary information about the water situation. Green water availability is more complex to calculate and refers to "total evapotranspiration of rainwater from land minus environmental green water requirements (the evapotranspiration from land reserved for natural vegetation) minus the evapotranspiration from land that cannot be made productive" ([22], p. 189).

While often treated as synonymous, there is an important distinction between water withdrawal (or water abstraction) and blue water consumption [22,50,51]. Water withdrawal is defined as freshwater taken from surface or ground water sources without accounting for how much is returned to the freshwater sources after use, whereas blue water consumption subtracts return flows from water withdrawal [47]. Blue water consumption refers to water that is (temporarily) lost from local hydrological systems due to evaporation or being incorporated into a product [47]. More specifically, after withdrawal from surface water and groundwater, water is either used for the production of goods and services (blue water consumption); consumed due to evaporation or transpiration (blue water consumption); directly discharged into the environment (return flows); or treated as wastewater and then discharged into the environment (return flows) [51].

Hoekstra et al. [22] defined human freshwater consumption in terms of water footprints, which are spatially and temporally explicit indicators, providing information on volume of water consumption, pollution, time and location. Specifically, the blue water footprint refers to volume of surface and groundwater consumed as a result of the production of goods and services [22]. The volume of rainwater consumed by agricultural and forestry products is referred to as the green water footprint, where it refers to "the total rainwater evapotranspiration (from fields and plantations) plus the water incorporated into the harvested crop or wood" ([22], p. 189). Hoekstra et al. [22] developed a definition of the "grey water footprint" to measure water pollution, which is "the volume of freshwater that is required to assimilate the load of pollutants based on natural background concentrations and existing ambient water quality standards"( [22], p. 190). The grey water footprint is essentially a hypothetical measure of water pollution which does not show actual water consumption nor provides any indication of pollution treatment costs [52,53], but it is seen as a good indicator to reflect the extent of water pollution [22].To assess blue water stress, water withdrawal and blue water consumption are two very different concepts. To quantify blue water use and blue water stress along supply chains, blue water consumption is usually used rather than water withdrawal [32]. The blue water footprint has been introduced to quantify direct water consumption as well as indirect or upstream blue water consumption over the entire supply chain [22]. To add to the confusion, also blue water footprints based on withdrawal can be frequently found in the literature due to data limitations $[54,55]$. 
Table 1. Definitions of physical water stress and scarcity.

\begin{tabular}{|c|c|c|c|}
\hline $\begin{array}{l}\text { Water Scarcity or } \\
\text { Water Stress }\end{array}$ & Definition & $\begin{array}{l}\text { Water Quantity or } \\
\text { Quality Dimension }\end{array}$ & Main References \\
\hline Water scarcity & $\begin{array}{l}\text { The fraction of the total annual run-off available } \\
\text { for human use }\end{array}$ & Quantity & {$[30,41]$} \\
\hline Water scarcity & $\begin{array}{c}\text { "The volumetric abundance, or lack thereof, of } \\
\text { freshwater resources" (p. 4) }\end{array}$ & Quantity & [47] \\
\hline Water scarcity & $\begin{array}{c}\text { "Water scarcity occurs where there are insufficient } \\
\text { water resources to satisfy long-term } \\
\text { average requirements" }\end{array}$ & Quantity & [56] \\
\hline Water scarcity & $\begin{array}{l}\text { "Extent to which demand for water compares to the } \\
\text { replenishment of water in an area, e.g., a drainage } \\
\text { basin, without taking into account the water quality" }\end{array}$ & Quantity & [57] \\
\hline Water scarcity & $\begin{array}{c}\text { "The ratio of sectoral water withdrawals of acceptable } \\
\text { water quality to the water availability" (p. 1) }\end{array}$ & Quality & [21] \\
\hline Blue water scarcity & $\begin{array}{c}\text { "The ratio of blue water footprint to blue } \\
\text { water availability" (p. 187) }\end{array}$ & Quantity & [22] \\
\hline Green water scarcity & $\begin{array}{l}\text { "The ratio of green water footprint to green } \\
\text { water availability" (p. 190) }\end{array}$ & Quantity & [22] \\
\hline Water stress & $\begin{array}{l}\text { "The impact of high water use (either withdrawals or } \\
\text { consumption) relative to water availability" (p. 2) }\end{array}$ & Quantity & [58] \\
\hline Water stress & $\begin{array}{l}\text { "The symptoms of water scarcity or shortage, e.g., } \\
\text { widespread, frequent and serious restrictions on use, } \\
\text { growing conflict between users and competition for } \\
\text { water, declining standards of reliability and service, } \\
\text { harvest failures and food insecurity" }\end{array}$ & Quantity & [59] \\
\hline Water stress & $\begin{array}{l}\text { "Water stress occurs when the demand for water } \\
\text { exceeds the available amount during a certain period } \\
\text { or when poor quality restricts its use. Water stress } \\
\text { causes deterioration of freshwater resources in terms } \\
\text { of quantity (aquifer over-exploitation, dry rivers, etc.) } \\
\text { and quality (eutrophication, organic matter pollution, } \\
\text { saline intrusion, etc.)" }\end{array}$ & Quantity and quality & {$[60]$} \\
\hline Water stress & $\begin{array}{l}\text { A logistic function of the ratio of total annual } \\
\text { freshwater withdrawals to hydrological availability, } \\
\text { and water stress ranges from } 0 \text { to } 1\end{array}$ & Quantity & [44] \\
\hline Water stress & $\begin{array}{l}\text { "The ability, or lack thereof, to meet human and } \\
\text { ecological demand for fresh water" (p. 4) }\end{array}$ & Quantity and quality & [47] \\
\hline Blue water stress & $\begin{array}{l}\text { "The ratio of total fresh water withdrawn by all sectors } \\
\text { to the water availability (total renewable freshwater } \\
\text { resources minus environmental flow requirements) in } \\
\text { a particular country or region" (p. 219) }\end{array}$ & Quantity & [32] \\
\hline
\end{tabular}

\section{Physical Water Stress Indicators}

Many indicators have been developed to evaluate water stress since the 1980s when it had been recognized as being a significant issue [4]. As there has been no consensus on how to define and measure water stress, different indicators have been developed. In this section, we focus on reviewing and comparing physical water stress indicators and ignore to discuss socio-economic aspects of water stress, such as economic water scarcity [61] and the water poverty index [62]. For a summary of water quantity and quality stress indicators see Table 2 . 
Table 2. Summary of indicators to measure physical water stress.

\begin{tabular}{|c|c|c|c|}
\hline Indicators & Quantification & Input Indicators & Main References \\
\hline $\begin{array}{l}\text { Water quality stress } \\
\text { (water pollution level) }\end{array}$ & $\begin{array}{l}\text { The ratio of grey water footprint to the } \\
\text { actual run-off }\end{array}$ & $\begin{array}{l}\text { (1) Grey water footprint } \\
\text { (2) Blue water resources }\end{array}$ & {$[19,21,22]$} \\
\hline Falkenmark indicator & Per capita annual run-off & $\begin{array}{l}\text { (1) Population } \\
\text { (2) Blue water resources }\end{array}$ & [41] \\
\hline Criticality ratio & $\begin{array}{l}\text { The ratio of withdrawal to blue } \\
\text { water resources }\end{array}$ & $\begin{array}{l}\text { (1) Water withdrawal } \\
\text { (2) Blue water resources }\end{array}$ & [42] \\
\hline $\begin{array}{l}\text { Pfister's water quantity } \\
\text { stress index }\end{array}$ & $\begin{array}{l}\text { A logistic function of the ratio of water } \\
\text { withdrawal to blue water resources }\end{array}$ & $\begin{array}{l}\text { (1) Water withdrawal } \\
\text { (2) Blue water resources }\end{array}$ & {$[44]$} \\
\hline Blue water scarcity & $\begin{array}{l}\text { The ratio of blue water footprint to blue } \\
\text { water availability (run-off minus } \\
\text { environmental flow requirements) }\end{array}$ & $\begin{array}{l}\text { (1) Blue water footprint } \\
\text { (2) Run-off } \\
\text { (3) Environmental } \\
\text { flow requirements }\end{array}$ & {$[27,41]$} \\
\hline Green water scarcity & Per capita available green water resources & $\begin{array}{l}\text { (1) Population } \\
\text { (2) Green water sources }\end{array}$ & [20] \\
\hline Green water scarcity & $\begin{array}{l}\text { The ratio of green water requirements for } \\
\text { self-sufficiency to green water availability }\end{array}$ & $\begin{array}{l}\text { (1) Green water requirements } \\
\text { for self-sufficiency } \\
\text { (2) Green water resources }\end{array}$ & {$[20]$} \\
\hline Green water scarcity & $\begin{array}{c}\text { The ratio of green water footprint to green } \\
\text { water availability (total green water } \\
\text { resources minus environmental green } \\
\text { water requirements) }\end{array}$ & $\begin{array}{l}\text { (1) Green water footprint } \\
\text { (2) Green water resources } \\
\text { (3) Environmental green } \\
\text { water requirements }\end{array}$ & {$[18,22]$} \\
\hline
\end{tabular}

\subsection{Per Capita Water Availability}

The per capita water availability index was introduced by Falkenmark et al. [41] to evaluate blue water stress, and is defined as the fraction of total annual run-off available for human use [41]. Falkenmark's indicator is simple and intuitive, and data on human population and annual run-off within regions are readily available. These merits make the Falkenmark indicator one of the most widely used blue water scarcity indicators [31]. As green water is important especially for agricultural products [18], this indicator has also been applied in the evaluation of green water scarcity, expressed as per capita green water resources in a region [20,49]. A combination of green and blue water scarcity has been developed to assess water stress caused by both green and blue water [49]. If green and blue water consumption in a certain area is less than the global average level of $1300 \mathrm{~m}^{3}$ /cap/year, then the area is considered as being water scarce [49]. Similarly, a combination of green and blue water consumption was used as part of the planetary boundaries concept that quantifies environmental limits within which humans can safely operate, with a global maximum water consumption of $4000 \mathrm{~km}^{3} /$ year $[49,63,64]$. Due to the simplicity of the indicator 'per capita water availability', there are a few inherent problems with this indicator: (i) this national and annual based indicator hides scarcity information at smaller spatial and temporal scales [30,31]; (ii) the thresholds ignore variations in demand among countries because of factors such as technology, lifestyle, and climate [30,31,65]; (iii) the indicator treats per capita water availability as a fixed requirement per person [31]; and (iv) it ignores important variations in demand and consumption among countries.

\subsection{Withdrawal-To-Availability Ratio}

The withdrawal-to-availability ratio is also referred to as a criticality ratio and is defined as "the ratio of average annual water withdrawals to water availability" ([42], p. 21). This ratio is a commonly used water quantity stress indicator, and has been widely applied to measure blue water stress in a given area [4,32]. A region can be categorized into severe water scarcity $(>40 \%)$, water scarcity $(20-40 \%)$, moderate water scarcity $(10-20 \%)$ and low water scarcity $(<10 \%)[42,66]$. The threshold values have been adopted by the United Nations [67], European Environment Agency [68] and numerous studies (e.g., [3,69,70]). The development of hydrological models in the past decades allows the modelling of blue 
water withdrawal and availability globally at a high spatial resolution [50,71,72], facilitating withdrawal-to-availability ratio-based assessments.

Pfister et al. [44] modified the withdrawal-to-availability ratio by using a logistic function providing water quantity stress levels at continuous values between 0 and 1 , in order to use the water quantity stress index as a characterization factor to calculate environmental impacts induced by water withdrawal in a life cycle assessment model. Pfister's water quantity stress index has also been linked to input-output models to convert water footprints into water stress footprints through weighing water footprints with water stress factors reflecting availability at the place of water extraction at high spatial resolution.

\subsection{Water Footprint-To-Availability Ratio}

It has been frequently argued that it makes more sense to use blue water consumption rather than water withdrawal to assess blue water stress [73,74], as the majority of the extracted blue water becomes eventually return flows, with only a small proportion of the actual water withdrawal being consumed. For example, estimates show that in agriculture, $40 \%$ of withdrawn water returns to rivers and lakes and $90 \%-95 \%$ of water withdrawn by industry and households flows back to nature [74]. Thus consumption-to-availability is seen as better suited to assess blue water stress than the withdrawal-to-availability ratio [22]. The consumption-to-availability ratio is generally used to measure blue water scarcity, which is the ratio between blue water consumption and availability. But green water scarcity and water pollution level defined by Hoekstra et al. [22] are also expressed as green/grey water footprint to availability ratio.

Limited green water aggravates water stress $[18,20]$. Even though green water has properties of both quantity and quality, the definition of green water just describes quantity. The quality of green water is determined by soil properties such as the concentration or retention capacity of nutrients and toxic substances [20]. At present, there is no relevant research on green water quality induced stress. The reason may be that green water quality in the soil is difficult to measure and the usefulness of green water quality assessment for practical purposes remains unclear. Green water scarcity specifically refers to green water quantity stress, and is defined as the ratio of the green water footprint to green water availability [22]. As measurements of green water availability and environmental green water requirements are difficult to obtain, the application of green water scarcity has received only limited attention in the literature $[18,20,22,28]$. The lack of opportunity costs of green water, i.e., the lack of competing uses in other sectors, is often stated as a reason to ignore green water $[75,76]$, which is thus considered as being less important for water management than blue water [77].

For water quality stress, there is one major indicator defined as the ratio of grey water footprint to the actual run-off, also referred to as water pollution level [22]. This indicator can be applied to assess water quality stress of freshwater $[19,21]$ or discharged wastewater from primary, secondary and tertiary economic sectors $[4,27,48,78]$. If water quality stress is over $100 \%$, it indicates that available blue water resources cannot dilute polluted water to satisfy water quality standards [22]. As it is a hypothetical indicator, the usefulness of the grey water footprint has been frequently questioned [52,79], yet these arguments have not abated the popularity of this indicator nor its frequent application $[17,21,27,48,78,80-82]$.

Calculating the grey water footprint is a precondition to measure water quality stress. Grey water footprint calculations created by Hoekstra et al. [22] are based on individual pollutants by selecting the highest grey water footprint of an individual pollutant. However, due to limited water pollution data availability [4], it is challenging to calculate the grey water footprint for all relevant pollutants and then to select the highest one as the final grey water footprint of polluted water. To solve this problem, major representative chemical water pollutants such as Chemical Oxygen Demand (COD) for measuring organic matters and Ammonia Nitrogen $\left(\mathrm{NH}_{3}-\mathrm{N}\right)$, Total Nitrogen (TN) and Total Phosphorus (TP) for nutrient pollution are the most frequently used pollutants to express water quality $[4,19,21,27,48,78]$, as these pollutants are commonly monitored for freshwater [83-85] or 
discharged wastewater $[86,87]$. In addition, physical parameters such as temperature and salinity (or electric conductivity) sometimes are also employed to evaluate water quality stress of surface water $[19,21]$.

However, only focusing on a representative and specific pollutant leaves other pollutants and their interactions unexamined $[88,89]$, which may lead to an underestimation of the grey water footprint and water quality stress. For instance, Vale et al. [90] pointed out that many studies on agricultural products, only considering fertilizers but ignoring pesticides, underestimate the grey water footprint. Similarly, when looking at industrial pollution, cadmium, copper and mercury are critical pollutants for steel production; whereas cadmium is a critical pollutant for cement; and for glass, a critical pollutant would be suspended solids [91]. In contrast, most studies on industrial sectors just chose the same conventional pollutants (i.e., COD and ammonia nitrogen) $[19,48]$. Thus, there is a need to investigate critical water pollutants for different processes or sectors providing a foundation for more accurate assessment of the grey water footprint and water quality stress.

To address this deficiency, cumulative effects of multiple pollutants have been the focus in recent studies [92-94], by combining footprint accounting with other tools, such as commonly used water quality evaluation tools [92], mass-balance models and fuzzy synthetic evaluation models [93]. But an important limitation of modified grey water footprint methods lies in the selection of pollutants, which requires calculation and analysis of pollution data in advance [92]. For this reason, traditional grey water footprint accounting is still dominating water quality stress assessments.

\section{Water Footprint Accounting}

\subsection{Bottom-Up Approaches}

Water footprint assessment (WFA) [22] and life cycle assessment (LCA) [95] are based on detailed data of individual processes and thus can be classed as bottom-up approaches [96]. WFA and LCA share a generic framework: setting goals and scope; accounting phase; impact assessment phase and interpretation [97]. WFA and LCA serve different goals, as life cycle assessment is a product-focused method, aiming to achieve sustainability of products, while water footprint assessment is a water management approach with a focus on the sustainability of water resources [97,98]. Water footprint assessment was developed with a focus on agricultural sectors and food production processes [79] at its early stage, then extended to industrial sectors, with currently focusing on agricultural and forestry-based production (such as paper, dairy and textile) and energy production (such as bioenergy and electricity) [99], whereas LCA had its starting point with a focus on industrial products and sectors. At the accounting stage of calculating the water footprint, the LCA and WFA communities have an ongoing debate about green and grey water footprint accounting. The WFA community measures blue, green and grey water footprints, but LCA only includes the blue water footprint [97]. The LCA community argues that only net green water (the difference between cropland and natural vegetation) should be counted [98], but it would lead to net negative green water footprints, because evapotranspiration of natural vegetation might be larger than that of croplands [98].Thus, it is unusual to account for green water footprints in LCA. The other issue is with regard to grey water footprint accounting, as the LCA community argues that different indicators such as acidification, eutrophication or toxicity potential are better suited to measure water pollution [79]. Even though LCA does not measure the grey water footprint directly, LCA databases have been applied in water footprint assessments to estimate grey water footprints [91]. For instance, LCA databases such as GaBi, Ecoinvent and Quantis can provide water pollution data for WFA [91,100], and also provide information on up-stream processes [101,102].

\subsection{Top-Down Approaches}

Top-down approaches provide a framework for quantification of environmental burdens based on national accounts that allows linking the entire supply chain in a production 
web to final consumption using macro-level approaches and concepts to analyze footprints of individuals, companies, sectors or regions [103]. At its core is the input-output (IO) table depicting monetary flows of goods and services among different economic sectors through trade [104]. IO analysis provides detailed flows between production and consumption at the level of economic sectors provided in national accounts of statistical offices. The input-output model with economic multipliers at its core allows not only the direct effects of environmental impacts through changes in final consumption but also the round-by-round or indirect effects of subsequent expenditures and inputs to each layer of production. This mechanism coupled with environmental extensions such as water consumption per sector enables the analyst to calculate the water footprint throughout the entire supply chain $[105,106]$.Such top-down water footprint accounting has a long history in input-output analysis $[107,108]$, even before the term water footprint was coined in 2002. Environmentally extended input-output analysis (EE-IO) is the most widely used top-down approach to calculate water consumption $[46,96,109]$.

Multi-Regional Input-Output (MRIO) analysis [104,110,111] and water embodied in bilateral trade $[46,96,112]$ are both input-output approaches that can be used to calculate water consumption. But the difference is that MRIO analysis traces global supply chains, while the method of water embodied in bilateral trade just traces domestic supply chains and imports. Thus, this difference may lead to inter-regional and international cut-off effects [96] and thus, wrong allocation of footprints [113].

IO and MRIO provide the most complete information about supply chains, whereas bottom-up approaches are not able to capture entire industrial supply chains, by focusing only at the most important processes, leading to inter-sector cut-off compared with topdown approaches $[73,96]$. System boundaries of bottom-up approaches can lead to double counting [114] as well as to excluding important flows [115]. A major drawback of inputoutput analysis is that economic sectors are aggregated and cannot show detailed process information compared with bottom-up approaches [116,117].

So-called hybrid analysis, linking process-based LCA and IO, combines advantages of both LCA and IO. There are three major approaches for hybrid analysis: tiered hybrid analysis [117-121], which essentially combines process and input-output data within a process analysis framework in order to reduce truncation error of a pure process analysis [116], IO-based hybrid analysis [117,118,122,123], which is performed by disaggregating industry sectors in the IO table to a more useful resolution, and integrated hybrid analysis $[100,117,124]$, which is carried out by connecting an input-output table to a technology matrix based on process data. These hybrid approaches have found a range of applications, for instance to quantify water consumption for wind power [125], shale gas [126], other electricity generation technologies [100], transport fuels [127], and non-electric energy (transport and heating energy) [128].

\section{Issues and Gaps in Water Stress Research}

\subsection{Lack of Standardized Approaches to Estimate Environmental Flow Requirements}

There is a slowly growing recognition that environmental flow requirements, which are "the quality, quantity, and timing of water flows required to maintain the components, functions, processes, and resilience of aquatic ecosystems" [129], need to be considered in the evaluation of water quantity stress $[4,32]$. However, current water quality stress evaluation seldom considers environmental flow requirements [48,78,80,81]. Even though there are more than 200 methods to estimate environmental flow requirements, which can be classified into hydrological methods; hydraulic rating methods; habitat simulation methods; and holistic methods (combination of hydrological, hydraulics, ecological, and social sciences) [130], it is still common to just use a certain percentage of total water resources as a proxy $[8,17,19,74,130-132]$, because calculating environmental flow requirements for a catchment is always an elaborate task [22]. However, there are huge uncertainties in these estimates [17] and they cannot easily be transferred to different geographic contexts. The choice of these proxies may have considerable effects on outcomes of water stress 
evaluation and associated recommendations. For example, Liu et al. [17] compared water quantity stress based on seven recommended proxies of environmental flow requirements which maintain different habitat quality of aquatic ecosystems and it turned out that water quantity stress estimates are quite different for different recommended environmental flow requirements. In addition, even less consideration is given to the water quality of environmental flow requirements, ignoring the fact that ecosystems require not only a certain quantity of water but also a minimum water quality to maintain different purposes and functions of freshwater ecosystem.

\subsection{Overlooked Return Flows}

In most cases, the water quality of return flows deteriorates during water use in production and consumption processes, contributing to water quality stress in a region. Despite its importance for water quality assessment, return flows have not received much attention in the literature. To mitigate water stress, deteriorated return flows can be treated by wastewater treatment facilities [133], rather than discharging return flows directly into the water body. At the same time, highly developed wastewater reuse technologies make it possible to recycle wastewater and alleviate blue water quantity stress. However, contributions of wastewater treatment and wastewater reclamation to reduce water quantity and quality stress are usually outside the system boundary of grey water footprint or water stress assessments. It is necessary to identify how flows return to nature and how quantity and quality of return flow changes on the way. Understanding return flows would be helpful to reduce water quantity and quality stress. For agricultural diffuse pollution, it is even more of a challenge to trace return flows and measure their impacts [22] despite the existence of models used to estimate the fraction of agricultural nitrogen pollutant that enter into water bodies [22].

\subsection{Lack of Teleconnections and Outsourcing of Water Pollution}

Another important issue related to the concept of footprints and especially virtual flows of water use and pollution is the problem of system boundaries and outsourcing of water problems to other areas. Resource consumption and environmental emissions are embedded in global supply chains via complex trade networks [134]. Therefore, local consumption activities may cause environmental impacts and resource depletion elsewhere, because of the role of teleconnections, which describe the linkages between spatially distant consumption and impacts $[134,135]$. Regions can shift water quantity and quality stress to other areas by importing water-intensive products and outsourcing water pollution. There are numerous studies on virtual water trade and reduction of domestic water quantity stress $[43,45,136-138]$. But there are only a few studies on outsourced water pollution and tele-connected water quality stress [139], due to challenges in quantification of pollution loads, availability of water pollution data and lack of clarity on how to best link water quality stress to the IO approach. Furthermore, both water quality stress locally and in remote areas should be considered at the same time to avoid spatial spillover effects and other unintended side effects. A focus on only one of them will lead to potentially severe underestimation of environmental impacts. But studies on considering water quantity and water quality stress simultaneously are still rare $[4,19,27,48]$. Making clear how water stress (both quantity and quality) is tele-connected would lay a foundation for policy making by providing information on water stress alleviation from trans-regional and trans-basin perspectives.

\subsection{Lack of Standardization of Definitions and Approaches}

There is still a lack of standardization in terms of definitions of basic concepts, objects and scope of the analysis and selected indicators. For instance, water quantity induced stress receives much attention while water quality stress is often overlooked [19,21]. This is partly due to the fact that many definitions of water stress or scarcity do not consider pollution induced water stress, which influences the subsequent selection of indicators [4]. 
Another example is the indiscriminate use of the terms water withdrawal and water consumption, which may lead to quite different results in water stress assessment because of their treatment of return flows. This difference may also have an impact on subsequent method selection. These two cases serve as examples of the importance of a wider agreement on key aspects of water stress assessment. These are preconditions to achieve more accurate and comparable results and conclusions, and would thus be better suited to support evidence-based policy making and implementation.

\section{Conclusions}

Water stress poses an important societal challenge. In this paper, we reviewed how to measure physical water stress, which is an important phase of water stress assessment. We defined and discussed a number of key concepts, i.e., water stress, scarcity, availability, consumption, withdrawal and the water footprint. Then we summarized three types of physical water stress indicators, covering water stress induced by quantity and quality. Subsequently, we reviewed bottom-up and top-down approaches to account for water footprints. Finally, we summarized issues and gaps in current water stress assessment: estimation of environmental flow requirements, outsourcing and teleconnections of water pollution, accounting for return flows, and standardization for water stress assessment. These problem areas can serve as venues for further research dealing with the evaluation and reduction of water stress.

Author Contributions: K.H., D.W. and Y.S. designed and prepared the draft of the manuscript, W.G.-L. and J.L. reviewed and edited the manuscript. All authors have read and agreed to the published version of the manuscript.

Funding: J.L. was funded by National Natural Science Foundation of China, grant number 41625001, the Strategic Priority Research Program of the Chinese Academy of Sciences, grant number XDA20060401, the High-level Special Funding of the Southern University of Science and Technology, grant numbers G02296302 and G02296402. D.W. was funded by China Scholarship Council, grant number 201908440332

Institutional Review Board Statement: Not applicable, for this study not involving humans or animals. Informed Consent Statement: Not applicable for this study not involving humans.

Data Availability Statement: No new data were created or analyzed in this study. Data sharing is not applicable to this article.

Acknowledgments: The authors thank the four reviewers for their constructive comments and suggestions, which helped improve the quality of this review paper.

Conflicts of Interest: The authors declare no conflict of interest. The funders had no role in the design of the study; in the collection, analyses, or interpretation of data; in the writing of the manuscript, or in the decision to publish the results.

\section{References}

1. Ercin, A.E.; Hoekstra, A.Y. Water Footprint Scenarios for 2050: A Global Analysis. Environ. Int. 2014, 64, 71-82. [CrossRef] [PubMed]

2. He, P.; Baiocchi, G.; Hubacek, K.; Feng, K.; Yu, Y. The Environmental Impacts of Rapidly Changing Diets and Their Nutritional Quality in China. Nat. Sustain. 2018, 1, 122-127. [CrossRef]

3. Vörösmarty, C.J.; Green, P.; Salisbury, J.; Lammers, R.B. Global Water Resources: Vulnerability from Climate Change and Population Growth. Science 2000, 289, 284-288. [CrossRef] [PubMed]

4. Liu, J.; Yang, H.; Gosling, S.N.; Kummu, M.; Flörke, M.; Pfister, S.; Hanasaki, N.; Wada, Y.; Zhang, X.; Zheng, C.; et al. Water Scarcity Assessments in the Past, Present, and Future: Review on Water Scarcity Assessment. Earth's Future 2017, 5, 545-559. [CrossRef] [PubMed]

5. Clarke, R. Water: The International Crisis; Routledge: Abingdon, UK, 2013; ISBN 978-1-134-15934-5.

6. Vörösmarty, C.J.; McIntyre, P.B.; Gessner, M.O.; Dudgeon, D.; Prusevich, A.; Green, P.; Glidden, S.; Bunn, S.E.; Sullivan, C.A.; Liermann, C.R.; et al. Global Threats to Human Water Security and River Biodiversity. Nature 2010, 467, 555-561. [CrossRef]

7. UN-Water. Sustainable Development Goal 6: Synthesis Report 2018 on Water and Sanitation; United Nations publications; United Nations: New York, NY, USA, 2018; ISBN 978-92-1-101370-2. 
8. Mekonnen, M.M.; Hoekstra, A.Y. Four Billion People Facing Severe Water Scarcity. Sci. Adv. 2016, 2, e1500323. [CrossRef]

9. UN. Transforming Our World: The 2030 Agenda for Sustainable Development; Springer: New York, NY, USA, 2015.

10. Prüss-Üstün, A.; Bos, R.; Gore, F.; Bartram, J. Safer Water, Better Health: Costs, Benefits and Sustainability of Interventions to Protect and Promote Health; World Health Organization: Geneva, Switzerland, 2008; ISBN 978-92-4-159643-5.

11. WHO. The World Health Report 2002: Reducing Risks, Promoting Healthy Life; World Health Organization: Geneva, Switzerland, 2002; ISBN 978-92-4-156207-2.

12. WHO. UNICEF 25 Years Progress on Sanitation and Drinking Water: 2015 Update and MDG Assessment; UNICEF and World Health Organization: Geneva, Switzerland, 2015; ISBN 978-92-4-150914-5.

13. Bhaduri, A.; Bogardi, J.; Siddiqi, A.; Voigt, H.; Vörösmarty, C.; Pahl-Wostl, C.; Bunn, S.E.; Shrivastava, P.; Lawford, R.; Foster, S.; et al. Achieving Sustainable Development Goals from a Water Perspective. Front. Environ. Sci. 2016, 4, 64. [CrossRef]

14. Vanham, D. Does the Water Footprint Concept Provide Relevant Information to Address the Water-Food-Energy-Ecosystem Nexus? Ecosyst. Serv. 2016, 17, 298-307. [CrossRef]

15. Blanc, D.L. Towards Integration at Last? The Sustainable Development Goals as a Network of Targets. Sustain. Dev. 2015, 23, 176-187. [CrossRef]

16. World Economic Forum. Global Risks 2015; World Economic Forum: Geneva, Switzerland, 2015.

17. Liu, J.; Liu, Q.; Yang, H. Assessing Water Scarcity by Simultaneously Considering Environmental Flow Requirements, Water Quantity, and Water Quality. Ecol. Indic. 2016, 60, 434-441. [CrossRef]

18. Schyns, J.F.; Hoekstra, A.Y.; Booij, M.J.; Hogeboom, R.J.; Mekonnen, M.M. Limits to the World's Green Water Resources for Food, Feed, Fiber, Timber, and Bioenergy. Proc. Natl. Acad. Sci. USA 2019, 116, 4893-4898. [CrossRef] [PubMed]

19. Ma, T.; Sun, S.; Fu, G.; Hall, J.W.; Ni, Y.; He, L.; Yi, J.; Zhao, N.; Du, Y.; Pei, T.; et al. Pollution Exacerbates China's Water Scarcity and Its Regional Inequality. Nat. Commun. 2020, 11, 1-9. [CrossRef] [PubMed]

20. Schyns, J.F.; Hoekstra, A.Y.; Booij, M.J. Review and Classification of Indicators of Green Water Availability and Scarcity. Hydrol. Earth Syst. Sci. 2015, 19, 4581-4608. [CrossRef]

21. Van Vliet, M.T.H.; Flörke, M.; Wada, Y. Quality Matters for Water Scarcity. Nat. Geosci. 2017, 10, 800-802. [CrossRef]

22. Hoekstra, A.Y.; Chapagain, A.K.; Mekonnen, M.M.; Aldaya, M.M. The Water Footprint Assessment Manual: Setting the Global Standard, 1st ed.; Earthscan: London, UK, 2011; ISBN 978-1-84977-552-6.

23. Hoekstra, A.Y.; Mekonnen, M.M. The Water Footprint of Humanity. Proc. Natl. Acad. Sci. USA 2012, 109, 3232-3237. [CrossRef]

24. Liu, J.; Zehnder, A.J.B.; Yang, H. Global Consumptive Water Use for Crop Production: The Importance of Green Water and Virtual Water. Water Resour. Res. 2009, 45, W05428. [CrossRef]

25. Rost, S.; Gerten, D.; Bondeau, A.; Lucht, W.; Rohwer, J.; Schaphoff, S. Agricultural Green and Blue Water Consumption and Its Influence on the Global Water System. Water Resour. Res. 2008, 44, W09405. [CrossRef]

26. UN-Water. Policy Brief on Water Quality; UN-Water: Geneva, Switzerland, 2011.

27. Zeng, Z.; Liu, J.; Savenije, H.H.G. A Simple Approach to Assess Water Scarcity Integrating Water Quantity and Quality. Ecol. Indic. 2013, 34, 441-449. [CrossRef]

28. Liu, J.; Zhao, D.; Mao, G.; Cui, W.; Chen, H.; Yang, H. Environmental Sustainability of Water Footprint in Mainland China. Geogr. Sustain. 2020, 1, 8-17. [CrossRef]

29. Liu, J.; Zhao, D. Three-Dimensional Water Scarcity Assessment by Considering Water Quantity, Water Quality, and Environmental Flow Requirements: Review and Prospect. Chin. Sci. Bull. Accept. 2020, 65, 4251-4261. [CrossRef]

30. Brown, A.; Matlock, M.D. A Review of Water Scarcity Indices and Methodologies; White Paper \#106; The Sustainability Consortium: Fayetteville, AR, USA, 2011.

31. Rijsberman, F.R. Water Scarcity: Fact or Fiction? Agric. Water Manag. 2006, 80, 5-22. [CrossRef]

32. Vanham, D.; Hoekstra, A.Y.; Wada, Y.; Bouraoui, F.; de Roo, A.; Mekonnen, M.M.; van de Bund, W.J.; Batelaan, O.; Pavelic, P.; Bastiaanssen, W.G.M.; et al. Physical Water Scarcity Metrics for Monitoring Progress towards SDG Target 6.4: An Evaluation of Indicator 6.4.2 "Level of Water Stress". Sci. Total Environ. 2018, 613-614, 218-232. [CrossRef] [PubMed]

33. Damkjaer, S.; Taylor, R. The Measurement of Water Scarcity: Defining a Meaningful Indicator. AMBIO 2017, 46, 513-531. [CrossRef] [PubMed]

34. Kummu, M.; Ward, P.J.; de Moel, H.; Varis, O. Is Physical Water Scarcity a New Phenomenon? Global Assessment of Water Shortage over the Last Two Millennia. Environ. Res. Lett. 2010, 5, 034006. [CrossRef]

35. Corbin, J.; Strauss, A. Basics of Qualitative Research: Techniques and Procedures for Developing Grounded Theory; Sage Publications: Thousand Oaks, CA, USA, 2014; ISBN 978-1-4833-1568-3.

36. Nouri, N.; Balali, F.; Nasiri, A.; Seifoddini, H.; Otieno, W. Water Withdrawal and Consumption Reduction for Electrical Energy Generation Systems. Appl. Energy 2019, 248, 196-206. [CrossRef]

37. Zhang, C.; Zhong, L.; Fu, X.; Wang, J.; Wu, Z. Revealing Water Stress by the Thermal Power Industry in China Based on a High Spatial Resolution Water Withdrawal and Consumption Inventory. Environ. Sci. Technol. 2016, 50, 1642-1652. [CrossRef]

38. Zhang, C.; Anadon, L.D. A Multi-Regional Input-Output Analysis of Domestic Virtual Water Trade and Provincial Water Footprint in China. Ecol. Econ. 2014, 100, 159-172. [CrossRef]

39. Distefano, T.; Kelly, S. Are We in Deep Water? Water Scarcity and Its Limits to Economic Growth. Ecol. Econ. 2017, 142, 130-147. [CrossRef] 
40. White, C. Understanding water scarcity: Definitions and measurements. In Global Water: Issues and Insights; Grafton, Q., Wyrwoll, P., White, C., Allendes, D., Eds.; ANU Press, The Australian National University: Canberra, Australia, 2014; ISBN 978-1-925021-67-7.

41. Falkenmark, M.; Lundqvist, J.; Widstrand, C. Macro-Scale Water Scarcity Requires Micro-Scale Approaches. Nat. Resour. Forum 1989, 13, 258-267. [CrossRef]

42. Alcamo, J.; Henrichs, T.; Rösch, T. World Water in 2025-Global Modeling and Scenario Analysis for the World Commission on Water for the 21st Century; Kassel World Water Series; University of Kassel: Kassel, Germany, 2000.

43. Feng, K.; Hubacek, K.; Pfister, S.; Yu, Y.; Sun, L. Virtual Scarce Water in China. Environ. Sci. Technol. 2014, 48, 7704-7713. [CrossRef] [PubMed]

44. Pfister, S.; Koehler, A.; Hellweg, S. Assessing the Environmental Impacts of Freshwater Consumption in LCA. Environ. Sci. Technol. 2009, 43, 4098-4104. [CrossRef] [PubMed]

45. White, D.J.; Feng, K.; Sun, L.; Hubacek, K. A Hydro-Economic MRIO Analysis of the Haihe River Basin's Water Footprint and Water Stress. Ecol. Model. 2015, 318, 157-167. [CrossRef]

46. Zhao, X.; Liu, J.; Liu, Q.; Tillotson, M.R.; Guan, D.; Hubacek, K. Physical and Virtual Water Transfers for Regional Water Stress Alleviation in China. Proc. Natl. Acad. Sci. USA 2015, 112, 1031-1035. [CrossRef] [PubMed]

47. CEO. Water Mandate Driving Harmonization of Water-Related Terminology; Pacific Institute: Oakland, CA, USA, 2014.

48. Zhao, X.; Liu, J.; Yang, H.; Duarte, R.; Tillotson, M.R.; Hubacek, K. Burden Shifting of Water Quantity and Quality Stress from Megacity Shanghai: Burden Shifting of Water Stress from Megacity Shanghai. Water Resour. Res. 2016, 52, 6916-6927. [CrossRef]

49. Rockström, J.; Falkenmark, M.; Karlberg, L.; Hoff, H.; Rost, S.; Gerten, D. Future Water Availability for Global Food Production: The Potential of Green Water for Increasing Resilience to Global Change. Water Resour. Res. 2009, 45, W00A12. [CrossRef]

50. Wada, Y.; Wisser, D.; Bierkens, M.F.P. Global Modeling of Withdrawal, Allocation and Consumptive Use of Surface Water and Groundwater Resources. Earth Syst. Dynam. 2014, 5, 15-40. [CrossRef]

51. Weckström, M.M.; Örmä, V.A.; Salminen, J.M. An Order of Magnitude: How a Detailed, Real-Data-Based Return Flow Analysis Identified Large Discrepancies in Modeled Water Consumption Volumes for Finland. Ecol. Indic. 2020, 110, 105835. [CrossRef]

52. Chenoweth, J.; Hadjikakou, M.; Zoumides, C. Review Article: Quantifying the Human Impact on Water Resources: A Critical Review of the Water Footprint Concept. Hydrol. Earth Syst. Sci. Discuss. 2013, 10, 9389-9433. [CrossRef]

53. Gawel, E.; Bernsen, K. Do We Really Need a Water Footprint? Global Trade, Water Scarcity and the Limited Role of Virtual Water. GAIA-Ecol. Perspect. Sci. Soc. 2011, 20, 162-167. [CrossRef]

54. Chen, Z.-M.; Chen, G.Q. Virtual Water Accounting for the Globalized World Economy: National Water Footprint and International Virtual Water Trade. Ecol. Indic. 2013, 28, 142-149. [CrossRef]

55. Cohen, E.; Ramaswami, A. The Water Withdrawal Footprint of Energy Supply to Cities. J. Ind. Ecol. 2014, 18, 26-39. [CrossRef]

56. European Environment Agency Water Use and Environmental Pressures. Available online: https://www.eea.europa.eu/themes/ water/european-waters/water-use-and-environmental-pressures/water-use-and-environmental-pressures\#toc-1 (accessed on 10 May 2020).

57. ISO. Environmental Management-Water Footprint_Principles, Requirements and Guidelines; International Organization for Standardization: Geneva, Switzerland, 2014; ISO 14046.

58. Kummu, M.; Guillaume, J.H.A.; de Moel, H.; Eisner, S.; Flörke, M.; Porkka, M.; Siebert, S.; Veldkamp, T.I.E.; Ward, P.J. The World's Road to Water Scarcity: Shortage and Stress in the 20th Century and Pathways towards Sustainability. Sci. Rep. 2016, 6, 1-16. [CrossRef] [PubMed]

59. AQUASTAT. AQUASTAT Database Glossary Search. Available online: http://www.fao.org/nr/water/aquastat/data/glossary/ search.html?cls=yes\&submitBtn=s\&d-49690-s=1\&d-49690-p=1\&d-49690-o=2\&termId=7579 (accessed on 18 December 2020).

60. European Environment Agency. Water Stress-European Environment Agency. Available online: https://www.eea.europa.eu/ archived/archived-content-water-topic/wise-help-centre/glossary-definitions/water-stress (accessed on 18 December 2020).

61. Seckler, D.; Amarasinghe, U.; Molden, D.; de Silva, R.; Barker, R. World Water Demand and Supply, 1990 to 2025: Scenarios and Issues; Research Report 19; International Water Management Institute: Colombo, Sri Lanka, 1998.

62. Sullivan, C.A.; Meigh, J.R.; Giacomello, A.M. The Water Poverty Index: Development and Application at the Community Scale. Nat. Resour. Forum 2003, 27, 189-199. [CrossRef]

63. Gerten, D.; Rockström, J.; Heinke, J.; Steffen, W.; Richardson, K.; Cornell, S. Response to Comment on "Planetary Boundaries: Guiding Human Development on a Changing Planet". Science 2015, 348, 1217. [CrossRef] [PubMed]

64. Steffen, W.; Richardson, K.; Rockström, J.; Cornell, S.E.; Fetzer, I.; Bennett, E.M.; Biggs, R.; Carpenter, S.R.; de Vries, W.; de Wit, C.A.; et al. Planetary Boundaries: Guiding Human Development on a Changing Planet. Science 2015, 347, 1259855. [CrossRef] [PubMed]

65. Savenije, H.H.G. Water Scarcity Indicators; the Deception of the Numbers. Phys. Chem. Earth Part B Hydrol. Ocean. Atmos. 2000, 25, 199-204. [CrossRef]

66. Raskin, P.; Gleick, P.; Kirshen, P.; Pontius, G.; Strzepek, K. Water Futures: Assessment of Long-Range Patterns and Problems; Stockholm Environment Institute: Stockholm, Sweden, 1997; ISBN 978-91-88714-45-9.

67. Raskin, P.; Gleick, P.; Kirshen, P.; Pontius, G.; Strzepek, K. Comprehensive Assessment of the Freshwater Resources of the World; Stockholm Environment Institute: Stockholm, Sweden, 1997. 
68. EEA. Water Resources across Europe: Confronting Water Scarcity and Drought; European Environment Agency: Copenhagen, Denmark, 2009.

69. Oki, T.; Agata, Y.; Kanae, S.; Saruhashi, T.; Yang, D.; Musiake, K. Global Assessment of Current Water Resources Using Total Runoff Integrating Pathways. Hydrol. Sci. J. 2001, 46, 983-995. [CrossRef]

70. Seckler, D.; Barker, R.; Amarasinghe, U. Water Scarcity in the Twenty-First Century. Int. J. Water Resour. Dev. 1999, 15, $29-42$. [CrossRef]

71. Flörke, M.; Kynast, E.; Bärlund, I.; Eisner, S.; Wimmer, F.; Alcamo, J. Domestic and Industrial Water Uses of the Past 60 Years as a Mirror of Socio-Economic Development: A Global Simulation Study. Glob. Environ. Chang. 2013, 23, 144-156. [CrossRef]

72. Hanasaki, N.; Kanae, S.; Oki, T.; Masuda, K.; Motoya, K.; Shirakawa, N.; Shen, Y.; Tanaka, K. An Integrated Model for the Assessment of Global Water Resources-Part 2: Applications and Assessments. Hydrol. Earth Syst. Sci. 2008, 12, $1027-1037$. [CrossRef]

73. Hoekstra, A.Y. Water Footprint Assessment in Supply Chains. In Sustainable Supply Chains: A Research-Based Textbook on Operations and Strategy; Bouchery, Y., Corbett, C.J., Fransoo, J.C., Tan, T., Eds.; Springer Series in Supply Chain Management; Springer: Cham, Germany, 2017; pp. 65-85. ISBN 978-3-319-29791-0.

74. Hoekstra, A.Y.; Mekonnen, M.M.; Chapagain, A.K.; Mathews, R.E.; Richter, B.D. Global Monthly Water Scarcity: Blue Water Footprints versus Blue Water Availability. PLoS ONE 2012, 7, e32688. [CrossRef] [PubMed]

75. Konar, M.; Dalin, C.; Hanasaki, N.; Rinaldo, A.; Rodriguez-Iturbe, I. Temporal Dynamics of Blue and Green Virtual Water Trade Networks. Water Resour. Res. 2012, 48. [CrossRef]

76. Yang, H.; Wang, L.; Abbaspour, K.C.; Zehnder, A.J.B. Virtual Water Trade: An Assessment of Water Use Efficiency in the International Food Trade. Hydrol. Earth Syst. Sci. Discuss. 2006, 10, 443-454. [CrossRef]

77. Hess, T. Estimating Green Water Footprints in a Temperate Environment. Water 2010, 2, 351-362. [CrossRef]

78. Wan, L.; Cai, W.; Jiang, Y.; Wang, C. Impacts on Quality-Induced Water Scarcity: Drivers of Nitrogen-Related Water Pollution Transfer under Globalization from 1995 to 2009. Environ. Res. Lett. 2016, 11, 074017. [CrossRef]

79. Yang, H.; Pfister, S.; Bhaduri, A. Accounting for a Scarce Resource: Virtual Water and Water Footprint in the Global Water System. Curr. Opin. Environ. Sustain. 2013, 5, 599-606. [CrossRef]

80. Mekonnen, M.M.; Hoekstra, A.Y. Global Gray Water Footprint and Water Pollution Levels Related to Anthropogenic Nitrogen Loads to Fresh Water. Environ. Sci. Technol. 2015, 49, 12860-12868. [CrossRef]

81. Mekonnen, M.M.; Hoekstra, A.Y. Global Anthropogenic Phosphorus Loads to Freshwater and Associated Grey Water Footprints and Water Pollution Levels: A High-Resolution Global Study. Water Resour. Res. 2018, 54, 345-358. [CrossRef]

82. Guan, D.; Hubacek, K. A New and Integrated Hydro-Economic Accounting and Analytical Framework for Water Resources: A Case Study for North China. J. Environ. Manag. 2008, 88, 1300-1313. [CrossRef]

83. Ouyang, Y.; Nkedi-Kizza, P.; Wu, Q.T.; Shinde, D.; Huang, C.H. Assessment of Seasonal Variations in Surface Water Quality. Water Res. 2006, 40, 3800-3810. [CrossRef]

84. Shrestha, S.; Kazama, F. Assessment of Surface Water Quality Using Multivariate Statistical Techniques: A Case Study of the Fuji River Basin, Japan. Environ. Model. Softw. 2007, 22, 464-475. [CrossRef]

85. Simeonov, V.; Stratis, J.A.; Samara, C.; Zachariadis, G.; Voutsa, D.; Anthemidis, A.; Sofoniou, M.; Kouimtzis, T. Assessment of the Surface Water Quality in Northern Greece. Water Res. 2003, 37, 4119-4124. [CrossRef]

86. Carey, R.O.; Migliaccio, K.W. Contribution of Wastewater Treatment Plant Effluents to Nutrient Dynamics in Aquatic Systems: A Review. Environ. Manag. 2009, 44, 205-217. [CrossRef] [PubMed]

87. Sun, Y.; Chen, Z.; Wu, G.; Wu, Q.; Zhang, F.; Niu, Z.; Hu, H.-Y. Characteristics of Water Quality of Municipal Wastewater Treatment Plants in China: Implications for Resources Utilization and Management. J. Clean. Prod. 2016, 131, 1-9. [CrossRef]

88. Martínez-Alcalá, I.; Pellicer-Martínez, F.; Fernández-López, C. Pharmaceutical Grey Water Footprint: Accounting, Influence of Wastewater Treatment Plants and Implications of the Reuse. Water Res. 2018, 135, 278-287. [CrossRef]

89. Wöhler, L.; Niebaum, G.; Krol, M.; Hoekstra, A.Y. The Grey Water Footprint of Human and Veterinary Pharmaceuticals. Water Res. X 2020, 7, 100044. [CrossRef]

90. Vale, R.L.; Netto, A.M.; Toríbio de Lima Xavier, B.; de Lâvor Paes Barreto, M.; Siqueira da Silva, J.P. Assessment of the Gray Water Footprint of the Pesticide Mixture in a Soil Cultivated with Sugarcane in the Northern Area of the State of Pernambuco, Brazil. J. Clean. Prod. 2019, 234, 925-932. [CrossRef]

91. Gerbens-Leenes, P.W.; Hoekstra, A.Y.; Bosman, R. The Blue and Grey Water Footprint of Construction Materials: Steel, Cement and Glass. Water Resour. Ind. 2018, 19, 1-12. [CrossRef]

92. Yu, C.; Yin, X.; Li, H.; Yang, Z. A Hybrid Water-Quality-Index and Grey Water Footprint Assessment Approach for Comprehensively Evaluating Water Resources Utilization Considering Multiple Pollutants. J. Clean. Prod. 2020, 248, 119225. [CrossRef]

93. Li, H.; Liu, G.; Yang, Z. Improved Gray Water Footprint Calculation Method Based on a Mass-Balance Model and on Fuzzy Synthetic Evaluation. J. Clean. Prod. 2019, 219, 377-390. [CrossRef]

94. Liu, W.; Antonelli, M.; Liu, X.; Yang, H. Towards Improvement of Grey Water Footprint Assessment: With an Illustration for Global Maize Cultivation. J. Clean. Prod. 2017, 147, 1-9. [CrossRef]

95. Guinée, J.B. Handbook on Life Cycle Assessment: Operational Guide to the ISO Standards; Kluwer Academic Publishers: Dordrecht, The Netherlands, 2002; ISBN 978-1-4020-0228-1. 
96. Feng, K.; Chapagain, A.; Suh, S.; Pfister, S.; Hubacek, K. Comparison of Bottom-up and Top-down Approaches to Calculating the Water Footprints of Nations. Econ. Syst. Res. 2011, 23, 371-385. [CrossRef]

97. Boulay, A.-M.; Hoekstra, A.Y.; Vionnet, S. Complementarities of Water-Focused Life Cycle Assessment and Water Footprint Assessment. Environ. Sci. Technol. 2013, 47, 11926-11927. [CrossRef] [PubMed]

98. Matuštík, J.; Kočí, V. What Is a Footprint? A Conceptual Analysis of Environmental Footprint Indicators. J. Clean. Prod. 2020, 124833. [CrossRef]

99. Zhuo, L.; Feng, B.; Wu, P. Water Footprint Study Review for Understanding and Resolving Water Issues in China. Water 2020, 12, 2988. [CrossRef]

100. Feng, K.; Hubacek, K.; Siu, Y.L.; Li, X. The Energy and Water Nexus in Chinese Electricity Production: A Hybrid Life Cycle Analysis. Renew. Sustain. Energy Rev. 2014, 39, 342-355. [CrossRef]

101. Kounina, A.; Margni, M.; Bayart, J.-B.; Boulay, A.-M.; Berger, M.; Bulle, C.; Frischknecht, R.; Koehler, A.; Milà i Canals, L.; Motoshita, M.; et al. Review of Methods Addressing Freshwater Use in Life Cycle Inventory and Impact Assessment. Int. J. Life Cycle. Assess. 2013, 18, 707-721. [CrossRef]

102. Paterson, W.; Rushforth, R.; Ruddell, B.L.; Konar, M.; Ahams, I.C.; Gironás, J.; Mijic, A.; Mejia, A. Water Footprint of Cities: A Review and Suggestions for Future Research. Sustainability 2015, 7, 8461-8490. [CrossRef]

103. Castellani, V.; Beylot, A.; Sala, S. Environmental Impacts of Household Consumption in Europe: Comparing Process-Based LCA and Environmentally Extended Input-Output Analysis. J. Clean. Prod. 2019, 240, 117966. [CrossRef]

104. Miller, R.E.; Blair, P.D. Input-Output Analysis: Foundations and Extensions; Cambridge University Press: New York, NY, USA, 2009.

105. Lenzen, M.; Foran, B. An Input-Output Analysis of Australian Water Usage. Water Policy 2001, 3, 321-340. [CrossRef]

106. Velázquez, E. An Input-Output Model of Water Consumption: Analysing Intersectoral Water Relationships in Andalusia. Ecol. Econ. 2006, 56, 226-240. [CrossRef]

107. Hartman, L.M. The Input-Output Model and Regional Water Management. J. Farm Econ. 1965, 47, 1583-1591. [CrossRef]

108. Isard, W. Ecologic-Economic Analysis for Regional Development; The Free Press: New York, NY, USA, 1972.

109. Hubacek, K.; Guan, D.; Barrett, J.; Wiedmann, T. Environmental Implications of Urbanization and Lifestyle Change in China: Ecological and Water Footprints. J. Clean. Prod. 2009, 17, 1241-1248. [CrossRef]

110. Acquaye, A.; Feng, K.; Oppon, E.; Salhi, S.; Ibn-Mohammed, T.; Genovese, A.; Hubacek, K. Measuring the Environmental Sustainability Performance of Global Supply Chains: A Multi-Regional Input-Output Analysis for Carbon, Sulphur Oxide and Water Footprints. J. Environ. Manag. 2017, 187, 571-585. [CrossRef] [PubMed]

111. Ewing, B.R.; Hawkins, T.R.; Wiedmann, T.O.; Galli, A.; Ertug Ercin, A.; Weinzettel, J.; Steen-Olsen, K. Integrating Ecological and Water Footprint Accounting in a Multi-Regional Input-Output Framework. Ecol. Indic. 2012, 23, 1-8. [CrossRef]

112. Peters, G.P.; Minx, J.C.; Weber, C.L.; Edenhofer, O. Growth in Emission Transfers via International Trade from 1990 to 2008. Proc. Natl. Acad. Sci. USA 2011, 108, 8903-8908. [CrossRef] [PubMed]

113. Hubacek, K.; Feng, K. Comparing Apples and Oranges: Some Confusion about Using and Interpreting Physical Trade Matrices versus Multi-Regional Input-Output Analysis. Land Use Policy 2016, 50, 194-201. [CrossRef]

114. Lenzen, M. Double-Counting in Life Cycle Calculations. J. Ind. Ecol. 2008, 12, 583-599. [CrossRef]

115. Daniels, P.L.; Lenzen, M.; Kenway, S.J. The Ins and Outs of Water Use-A Review of Multi-Region Input-Output Analysis and Water Footprints for Regional Sustainability Analysis and Policy. Econ. Syst. Res. 2011, 23, 353-370. [CrossRef]

116. Crawford, R.H.; Bontinck, P.-A.; Stephan, A.; Wiedmann, T.; Yu, M. Hybrid Life Cycle Inventory Methods-A Review. J. Clean. Prod. 2018, 172, 1273-1288. [CrossRef]

117. Suh, S.; Huppes, G. Methods for Life Cycle Inventory of a Product. J. Clean. Prod. 2005, 13, 687-697. [CrossRef]

118. Joshi, S. Product Environmental Life-Cycle Assessment Using Input-Output Techniques. J. Ind. Ecol. 1999, 3, 95-120. [CrossRef]

119. Lenzen, M. Dealing with Double-Counting in Tiered Hybrid Life-Cycle Inventories: A Few Comments. J. Clean. Prod. 2009, 17, 1382-1384. [CrossRef]

120. Strømman, A.H.; Peters, G.P.; Hertwich, E.G. Approaches to Correct for Double Counting in Tiered Hybrid Life Cycle Inventories. J. Clean. Prod. 2009, 17, 248-254. [CrossRef]

121. Suh, S.; Huppes, G. Missing Inventory Estimation Tool Using Extended Input-Output Analysis. Int. J. Life Cycle Assess. 2002, 7, 134-140. [CrossRef]

122. Dixit, M.K. Embodied Energy Analysis of Building Materials: An Improved IO-Based Hybrid Method Using Sectoral Disaggregation. Energy 2017, 124, 46-58. [CrossRef]

123. Dixit, M.K.; Culp, C.H.; Fernandez-Solis, J.L. Embodied Energy of Construction Materials: Integrating Human and Capital Energy into an IO-Based Hybrid Model. Environ. Sci. Technol. 2015, 49, 1936-1945. [CrossRef]

124. Wiedmann, T.O.; Suh, S.; Feng, K.; Lenzen, M.; Acquaye, A.; Scott, K.; Barrett, J.R. Application of Hybrid Life Cycle Approaches to Emerging Energy Technologies-The Case of Wind Power in the UK. Environ. Sci. Technol. 2011, 45, 5900-5907. [CrossRef]

125. Li, X.; Feng, K.; Siu, Y.L.; Hubacek, K. Energy-Water Nexus of Wind Power in China: The Balancing Act between $\mathrm{CO}_{2}$ Emissions and Water Consumption. Energy Policy 2012, 45, 440-448. [CrossRef]

126. Gao, J.; You, F. Integrated Hybrid Life Cycle Assessment and Optimization of Shale Gas. ACS Sustain. Chem. Eng. 2018, 6, 1803-1824. [CrossRef]

127. Harto, C.; Meyers, R.; Williams, E. Life Cycle Water Use of Low-Carbon Transport Fuels. Energy Policy 2010, $38,4933-4944$. [CrossRef] 
128. Liu, S.; Wang, C.; Shi, L.; Cai, W.; Zhang, L. Water Conservation Implications for Decarbonizing Non-Electric Energy Supply: A Hybrid Life-Cycle Analysis. J. Environ. Manag. 2018, 219, 208-217. [CrossRef] [PubMed]

129. Poff, N.L.; Richter, B.D.; Arthington, A.H.; Bunn, S.E.; Naiman, R.J.; Kendy, E.; Acreman, M.; Apse, C.; Bledsoe, B.P.; Freeman, M.C.; et al. The Ecological Limits of Hydrologic Alteration (ELOHA): A New Framework for Developing Regional Environmental Flow Standards. Freshw. Biol. 2010, 55, 147-170. [CrossRef]

130. Pastor, A.V.; Ludwig, F.; Biemans, H.; Hoff, H.; Kabat, P. Accounting for Environmental Flow Requirements in Global Water Assessments. Hydrol. Earth Syst. Sci. 2014, 18, 5041-5059. [CrossRef]

131. Munia, H.A.; Guillaume, J.H.A.; Wada, Y.; Veldkamp, T.; Virkki, V.; Kummu, M. Future Transboundary Water Stress and Its Drivers Under Climate Change: A Global Study. Earth's Future 2020, 8, e2019EF001321. [CrossRef]

132. Richter, B.D.; Davis, M.M.; Apse, C.; Konrad, C. A Presumptive Standard for Environmental Flow Protection. River Res. Appl. 2012, 28, 1312-1321. [CrossRef]

133. Voulvoulis, N. Water Reuse from a Circular Economy Perspective and Potential Risks from an Unregulated Approach. Curr. Opin. Environ. Sci. Health 2018, 2, 32-45. [CrossRef]

134. Hubacek, K.; Feng, K.; Minx, J.; Pfister, S.; Zhou, N. Teleconnecting Consumption to Environmental Impacts at Multiple Spatial Scales-Research Frontiers in Environmental Footprinting. J. Ind. Ecol. 2014, 18, 7-9. [CrossRef]

135. Yu, Y.; Feng, K.; Hubacek, K. Tele-Connecting Local Consumption to Global Land Use. Glob. Environ. Chang. 2013, 23, 1178-1186. [CrossRef]

136. Cai, B.; Zhang, W.; Hubacek, K.; Feng, K.; Li, Z.; Liu, Y.; Liu, Y. Drivers of Virtual Water Flows on Regional Water Scarcity in China. J. Clean. Prod. 2019, 207, 1112-1122. [CrossRef]

137. Munoz Castillo, R.; Feng, K.; Hubacek, K.; Sun, L.; Guilhoto, J.; Miralles-Wilhelm, F. Uncovering the Green, Blue, and Grey Water Footprint and Virtual Water of Biofuel Production in Brazil: A Nexus Perspective. Sustainability 2017, 9, 2049. [CrossRef]

138. Munoz Castillo, R.; Feng, K.; Sun, L.; Guilhoto, J.; Pfister, S.; Miralles-Wilhelm, F.; Hubacek, K. The Land-Water Nexus of Biofuel Production in Brazil: Analysis of Synergies and Trade-Offs Using a Multiregional Input-Output Model. J. Clean. Prod. 2019, 214, 52-61. [CrossRef]

139. Wu, Z.; Ye, Q. Water Pollution Loads and Shifting within China's Inter-Province Trade. J. Clean. Prod. 2020, 259, 120879. [CrossRef] 